\title{
Intestinal morphology and growth performance of the Indonesian indigenous crossbred chickens supplemented with formic acid and Saccharomyces cerevisiae
}

\author{
S.N. Erya, H.I. Wahyuni, T. Yudiarti, E. Widiastuti and S. Sugiharto* \\ Department of Animal Science, Faculty of Animal and Agricultural Sciences, Diponegoro University, \\ Semarang 50275, Central Java - Indonesia \\ *Corresponding E-mail: sgh_undip@yahoo.co.id
}

Received June 25, 2020; Accepted August 10, 2020

\begin{abstract}
ABSTRAK
Penelitian bertujuan mengevaluasi kondisi ekologi dan morfologi usus ayam kampung super (AKS) yang disuplementasi dengan campuran asam format dan Saccharomyces cerevisiae. Sebanyak 200 AKS didistribusikan ke T0 (pakan basal tanpa suplemen), T1 (T0+ 0,2\% asam format), T2 (T0+ 0,3\% $S$. cerevisiae), T3 (T0+0,2\% asam format dan $0,3 \%$ S. cerevisiae). Total koleksi dilakukan pada minggu ke8, sedangkan pengamatan ekologi dan morfologi usus pada minggu ke-9. Ayam T3 memiliki villi duodenum lebih tinggi $(\mathrm{P}<0,05)$ dan lebih lebar $(\mathrm{P}<0,05)$. Ayam T2 dan T3 memiliki kripta lebih dalam $(\mathrm{P}<0,05)$ dibandingkan T0. Vili jejunum lebih tinggi $(\mathrm{P}<0,05)$ pada T3 daripada T0. Ayam T3 memiliki kripta lebih dalam $(\mathrm{P}<0,05)$ daripada ayam lainnya. Di ileum, T0 memiliki villi paling rendah $(\mathrm{P}<0,05)$ dibandingkan lainnya. Kripta lebih dalam $(\mathrm{P}<0,05)$ di $\mathrm{T} 3$ daripada ayam lainnya. Ayam $\mathrm{T} 1$ memiliki koefisien kecernaan protein kasar tertinggi $(\mathrm{P}<0,05)$ dan protein kasar ekskreta terendah dibandingkan kelompok lainnya. Dibandingkan kontrol, AKS perlakuan menunjukkan pertambahan bobot badan dan konsumsi pakan lebih tinggi $(\mathrm{P}<0,05)$, dengan efisiensi penggunaan pakan yang tidak berbeda $(\mathrm{P}>0,05)$. T3 menunjukkan bobot badan dan konsumsi tertinggi dengan efisien pakan terendah. Kesimpulannya, penggunaan asam format dan S. cerevisiae dalam pakan memperbaiki ekologi dan morfologi usus. AKS yang diberi pakan mengandung asam format dan $S$. cerevisiae menunjukkan perbaikan performa pertumbuhan dan kecernaan.
\end{abstract}

Kata kunci : ayam kampung super, asam format, Saccharomyces cerevisiae, pertumbuhan

\section{ABSTRACT}

The study investigated gut ecology and morphology of the Indonesian indigenous crossbred chickens (IICC) supplemented with the combination of formic acid and Saccharomyces cerevisiae. Two hundreds day-old IICC were distributed to T0 (control diet), T1 (T0 + 0.2\% formic acid), T2 (T0 + 0.3\% S. cerevisiae), T3 (T0 $+0.2 \%$ formic acid and $0.3 \%$ S. cerevisiae). Excreta was collected at week 8 , while intestinal ecology and morphology were determined at week 9. In duodenum, T3 chicks showed higher and wider $(\mathrm{P}<0.05)$ villi. The $\mathrm{T} 2$ and $\mathrm{T} 3$ chicks showed deeper $(\mathrm{P}<0.05)$ crypt than that of $\mathrm{T} 0$. The jejunal villi was higher $(\mathrm{P}<0.05)$ in $\mathrm{T} 3$ than in $\mathrm{T} 0$. The $\mathrm{T} 3$ chicks had deeper $(\mathrm{P}<0.05)$ crypt compared to other groups. In ileum, the villi height was lowest $(\mathrm{P}<0.05)$ in $\mathrm{T} 0$. The crypt was deeper $(\mathrm{P}<0.05)$ in $\mathrm{T} 3$ than in other. Crude protein digestibility coefficient was highest $(\mathrm{P}<0.05)$, while fecal protein was loswest $(\mathrm{P}<0.05)$ in $\mathrm{T} 1$ than in other groups. Compared to $\mathrm{T} 0$, the treated IICC showed higher $(\mathrm{P}<0.05)$ weight gain and feed intake with $\mathrm{T} 3 \mathrm{had}$ the highest gain and intake but gain:feed rasio 
was the lowest $(\mathrm{P}>0.05)$. In conclusion, the inclusion of formic acid and $S$. cerevisiae in diets improved intestinal ecology and morphology. The IICC chickens fed with formic acid and $S$. cerevisiae exhibited improved growth performance and nutrient digestibility.

Keywords: crossbred chickens, organic acid, Saccharomyces cerevisiae, growth rate

\section{INTRODUCTION}

The demand for the Indonesian indigenous crossbred chicken (IICC) meat has been increasing in the recent time. The IICC is a crossbred between male Indonesian indigenous chicken and commercial laying hen. Compared to the indigenous chickens, the IICC may need shorter period to harvest (Herlina and Ibrahim, 2019). Also, they are more adaptive to the surrounding environment when compared with the modern broiler strains (Darmawan et al., 2017). For this reason, the IICC is very potential to be developed as meat producer and to drive the economic development. Antibiotic growth promoter (AGP) had formerly been incorporated into the feed to promote the growth and health condition of the IICC (Sugiharto et al., 2018). However, such practice is now globally prohibited due to food safety reason. Owing to the essential role of AGP in IICC growth and health, it is therefore urgent to find alternatives to AGP for the sustainable IICC production.

Intestine is part of the digestive organs that plays crucial roles in feed digestion and nutrient absorption. In general, the utilization of nutrients from feed can be maximized when intestinal function and health are maintained optimally. Morphology and microbial population in the intestine may in general indicate the intestinal function and health in poultry. The height and width of villus as well as the depth of crypt are common indicators that nutritionists often use to evaluate the performance of the intestine in digesting and absorbing the dietary nutrients (Harimurti and Rahayu, 2009). Intestinal villi is a place where the absorption of nutrients occur, so that the higher and wider of the villi may allow for more absorption of nutrient by the chickens. Moreover, the height and width of villi may also reflect the health of the intestine (Awad et al., 2009). With regard to the microbial population, the balance of microorganisms in the intestine has a very crucial role in preserving the morphological and intestinal health. Indeed, the increased counts of good or beneficial microbes and the decreased pathogenic bacteria are highly correlated with the improved health and production performance of chickens (Widodo et al., 2015).

Formic acid is an organic acid that can be administrated as an alternative to AGP. As an acidifier, formic acid is very effective in reducing gut $\mathrm{pH}$, and increasing intestinal villi height and body weight gain of poultry (Phatak et al., 2017). Formic acid can also prevent chickens from intestinal infections caused by Salmonella $(S$. typhimurium, $S$. senftenberg and $S$. putten; Koyuncu et al., 2013) and Escherichia coli (Garcia et al, 2007). However, formic acid may irritate the intestine when given in high doses (Ramli et al., 2008). Saccharomyces cerevisiae is a microorganism that has commonly been used as a probiotic to improve the gut functions of chickens (Kompiang, 2002). The cell wall of $S$. cerevisiae ( $\beta$ 1,3 and 1,6 glucans) can repair the damaged tissue as well as control intestinal inflammation due to infection or toxin (Ahmad, 2005). The nucleotide content in S. cerevisiae is also able to restore the damage of intestinal mucosa and improve intestinal flora (Li et al., 2007). To grow better, $S$. cerevisiae requires an acidic $\mathrm{pH}$, which is between 4.0-4.5 (Ahmad, 2005). On this basis, creating an acid condition in the intestine would promote the growth and hence probiotic function of $S$. cerevisiae on chickens.

Sugiharto (2016) pointed out that the application of a mixture of probiotics with other active ingredients can improve the efficacy of probiotics in substituting AGP. In this study $S$. cerevisiae was combined with formic acid with the hope that the role of $S$. cerevisiae would be more effective in improving the gut ecology and morphology of IICC. For the note, the acidic conditions in the gut caused by the action of formic acid was expected to improve the development and probiotic functions of $S$. cerevisiae in the intestine. Also, a synergistic effect was expected to occur between formic acid and $S$. cerevisiae in improving the intestinal conditions of IICC. To best of our knowledge, the combined effect of formic acid and S. cerevisiae on the intestinal ecology of the IICC has never been published. Hence, this study aimed to examine the gut ecology and morphology of the IICC supplemented with the mixture of formate 
and $S$. cerevisiae.

\section{MATERIALS AND METHODS}

\section{Preparations of feeds and supplements}

The feed was prepared as a basal ration based on yellow corn and soybean meal (Table 1). The supplements were included at the end of the mixing process of feed. Formic acid (Baymix Latibon ${ }^{\circledR P l u s}$ ME) used was provided by PT. Bayer Indonesia, while S. cerevisiae (Mauripan ${ }^{\circledR}$ ) was obtained from PT. Jaya Fermex, Jakarta, Indonesia.

\section{In vivo Experiment}

For the in vivo trial, 200 day-old IICC were used. At the initial, they were weighed (average body weight of $38.05 \pm 0.35 \mathrm{~g}$ ) and distributed randomly to four treatments with five replicates per treatment and 10 chicks per pen. Chicks were fed starter (week 1-4) and finisher (week 5-9) diets (Table 1). Dietary treatments were unsuplemented diet (T0), supplemented with $0.2 \%$ formic acid ( $\mathrm{T} 1$ or $\mathrm{T} 0+0.2$ formic acid), supplemented with $0.3 \%$ S. cerevisiae (T2 or T0 + $0.3 S$. cerevisiae) or supplemented with the mixture of $0.2 \%$ formic acid and $0.3 \% S$. cerevisiae (T3 or $\mathrm{T} 0+0.2$ formic acid $+0.3 \mathrm{~S}$. cerevisiae). Birds had free access to diet and drinking water. Vaccination was performed at 4 and 30 days using Newcastle disease vaccine. Feed consumption was determined daily, while the weight of chickens was recorded at weekly basis.

Table 1. Compositions and Nutrient Contents of Basal Diets for IICC (as-Fed Basis)

\begin{tabular}{lcc}
\hline \multicolumn{1}{c}{ Ingredients (\%) } & Week 1-4 & Week 5-9 \\
\hline Yellow corn & 54.75 & 58.50 \\
Meat bone meal & 4.75 & 2.00 \\
Soybean oil & 1.50 & 3.50 \\
Soybean meal & 35.75 & 32.75 \\
DL-methionine & 0.30 & 0.30 \\
L-lysine & 0.20 & 0.20 \\
Limestone & 0.50 & 0.50 \\
Dicalcium phosphate & 1.50 & 1.50 \\
Premix ${ }^{1}$ & 0.50 & 0.50 \\
NaCl & 0.25 & 0.25 \\
Analyzed nutrient contents & & \\
Metabolisable energy (kcal $/ \mathrm{kg})^{2}$ & 3315 & 3474 \\
Crude protein (\%) & 19.02 & 17.14 \\
Crude fat (\%) & 4.39 & 6.51 \\
Crude fiber (\%) & 7.65 & 6.96 \\
Ash (\%) & 6.97 & 5.83 \\
\hline
\end{tabular}

${ }^{1}$ Premix contained (per kg of diet) of vit A $7750 \mathrm{IU}$, vit $\mathrm{D}_{3} 1550 \mathrm{IU}$, vit $\mathrm{E} 1.88 \mathrm{mg}$, vit $\mathrm{B}_{1} 1.25 \mathrm{mg}$, vit $\mathrm{B}_{2} 3.13$ $\mathrm{mg}$, vit $\mathrm{B}_{6} 1.88 \mathrm{mg}$, vit $\mathrm{B}_{12} 0.01 \mathrm{mg}$, vit C $25 \mathrm{mg}$, folic acid $1.50 \mathrm{mg}$, Ca-D-pantothenate $7.5 \mathrm{mg}$, niacin 1.88 $\mathrm{mg}$, biotin $0.13 \mathrm{mg}$, BHT $25 \mathrm{mg}$, Co $0.20 \mathrm{mg}$, Cu $4.35 \mathrm{mg}$, Fe $54 \mathrm{mg}$, I $0.45 \mathrm{mg}$, Mn $130 \mathrm{mg}$, Zn $86.5 \mathrm{mg}$, Se $0.25 \mathrm{mg}$, L-lysine $80 \mathrm{mg}$, Choline chloride $500 \mathrm{mg}$, DL-methionine $900 \mathrm{mg}, \mathrm{CaCO}_{3} 641.5 \mathrm{mg}$, dicalcium phosphate $1500 \mathrm{mg}$.

${ }^{2}$ Metabolisable energy was determined based on formula (Bolton, 1967) i.e.: $40.81\{0.87$ [crude protein + 2.25 crude fat + nitrogen-free ex-tract $]+2.5\}$ 


\section{Sample Collections}

On wk 8, one bird was randomly taken from each experimental pen (20 birds from a total of four treatments) to exert total excreta collection. The total excreta collection was conducted for seven days until week $9 . \mathrm{Fe}_{2} \mathrm{O}_{3}$ was mixed with each experimental diet and futher used as an indicator during the total excreta collection (Sutrisno et al., 2013). The collected excreta was cleaned from feathers and debris, sprayed using $\mathrm{HCl} 0.2 \mathrm{~N}$ and weighed. The excreta was sundried and then homogenized. The homogenized excreta was analyzed for their contents of crude protein using the Kjeldahl method. Nitrogen retention was calculated based on Tillman et al. (1998).

At week 9, the IICC used for total excreta collection were slaughtered and dissected. The digestive tract of chicks were taken, and $2 \mathrm{~cm}$ of gut segments (duodenum, jejenum and ileum) were removed and put in a sample bottle containing $10 \%$ neutral buffered formalin for histopathological analysis. Digesta was collected from the small intestine and cecum for $\mathrm{pH}$ measurement (using the $\mathrm{pH}$ Test tool brand Eco Testr $\mathrm{pH}$ 1) and microbiological analysis. The number of bacteria was calculated based on Sugiharto et al. (2019), at which the total lactic acid bacteria (LAB) was determined on de Man,
Rogosa and Sharpe agar (Merck KGaA, Darmstadt, Germany) after anaerobic incubation at $38^{\circ} \mathrm{C}$ for 48 hours, while the total coliform and lactose-negative enterobacteria were determined on MacConkey agar (Merck KGaA, Darmstadt, Germany) as red and white (colorless) colonies after aerobic incubation at $38^{\circ} \mathrm{C}$ for 24 hours.

Histopathological analysis of the small intestinal segments was carried out by haematoxylin-eosin (HE) staining. The measurements of gut morphology was carried out using an optical microscope fiited to a digital camera (Leica Microsystems GmbH, Wetzlar, Germany). The three best villi were selected for each gut segment in one slide and then measured.

\section{Statistical Analysis}

Data were subjected to analysis of variance (ANOVA) using the statistical software of SPPS (IBM SPSS Statistic version 23) and followed by Duncan multiple range test (SPSS) at 5\% significance level (SPSS). The data are presented in a mean value \pm standard deviation.

\section{RESULTS}

\section{Intestinal Ecology of the IICC}

The data on $\mathrm{pH}$ values and selected bacterial

Table 2. $\mathrm{pH}$ Values and Selected Bacterial Populations in the Gut of IICC

\begin{tabular}{lccccc}
\hline \multirow{2}{*}{ Items } & \multicolumn{5}{c}{ Treatments } \\
\cline { 2 - 5 } & T0 & T1 & T2 & T3 value & \\
\hline pH values & & & & & \\
Duodenum & $6.18 \pm 0.52$ & $6.14 \pm 0.73$ & $5.94 \pm 0.66$ & $5.84 \pm 0.55$ & 0.79 \\
Jejunum & $5.58 \pm 0.52$ & $5.30 \pm 0.51$ & $5.90 \pm 0.62$ & $6.02 \pm 0.87$ & 0.32 \\
Ileum & $5.58 \pm 1.17$ & $5.62 \pm 1.29$ & $5.86 \pm 0.74$ & $5.64 \pm 0.99$ & 0.97 \\
Caecum & $6.48 \pm 0.52$ & $6.26 \pm 0.49$ & $6.76 \pm 0.60$ & $6.58 \pm 1.11$ & 0.74 \\
Ileal bacterial counts (log cfu/g) & & & & & \\
Coliform & $3.38 \pm 1.51$ & $4.52 \pm 3.28$ & $6.04 \pm 3.42$ & $4.84 \pm 4.45$ & 0.33 \\
Lactose-negative enterobacteria & $7.36 \pm 4.14$ & $8.57 \pm 1.34$ & $6.74 \pm 3.96$ & $9.15 \pm 0.81$ & 0.57 \\
Lactic acid bacteria & $10.7 \pm 1.01$ & $10.6 \pm 0.75$ & $10.9 \pm 1.08$ & $11.2 \pm 0.47$ & 0.67 \\
Caecal bacterial counts (log cfu/g) & & & & & \\
Coliform & $8.97 \pm 0.87$ & $9.11 \pm 0.77$ & $9.10 \pm 0.70$ & $8.99 \pm 0.43$ & 0.98 \\
Lactose-negative enterobacteria & $8.73 \pm 0.77$ & $9.18 \pm 0.72$ & $8.16 \pm 0.40$ & $8.59 \pm 0.98$ & 0.23 \\
Lactic acid bacteria & $11.6 \pm 0.21$ & $11.4 \pm 0.45$ & $11.4 \pm 0.37$ & $11.5 \pm 0.27$ & 0.90 \\
\hline
\end{tabular}

T0: unsuplemented feed (control), T1: T0 $+0.2 \%$ formic acid, T2: T0 + 0.3\% S. cerevisiae, T3: T0 + 0.2\% formic acid $+0.3 \%$ S. cerevisiae 
populations in the gut of IICC are listed in Table 2 . In general, the $\mathrm{pH}$ values and bacterial counts in the intestine of IICC were not substantially impacted by the treatments.

\section{Intestinal Morphology of the IICC}

The intestinal morphology of IICC is detailed in Table 3. In duodenum, the chicks in T3 showed higher $(\mathrm{P}<0.05)$ villi height and wider $(\mathrm{P}<0.05)$ villi width than other chicken groups. The T2 and T3 chicks showed deeper $(\mathrm{P}<0.05)$ crypt depth than that of T0, while T1 did not significantly differ from $\mathrm{T} 0$ and $\mathrm{T} 2$. The jejunal villi was higher $(\mathrm{P}<0.05)$ in $\mathrm{T} 3$ than in $\mathrm{T} 0$, but did not differ from $\mathrm{T} 1$ and $\mathrm{T} 2$. The $\mathrm{T} 3$ chicks also had deeper $(\mathrm{P}<0.05)$ crypth depth than that of other treatments. In ileum, the villi height was lowest $(\mathrm{P}<0.05)$ in $\mathrm{T} 0$ than that in other treated groups. The crypt depth was deeper $(\mathrm{P}<0.05)$ in $\mathrm{T} 3$ than in other chicken groups. The villi width of jejunum and ileum were not divergent $(\mathrm{P}>0.05)$ among the IICC.

\section{Protein Digestibility and Nitrogen Retention}

The digestibility of protein and nitrogen retention of IICC are detailed in Table 4. Crude protein digestibility coefficient was highest $(\mathrm{P}<0.05)$, while fecal crude protein was loswest in $\mathrm{T} 1$ than in other treatment groups. Crude protein intake, digestible crude protein and nitrogen retention were not significantly divergent among the dietary treatments.

\section{Performances of IICC}

Compared to T0, the treated IICC showed higher $(\mathrm{P}<0.05)$ weight gain and feed consumption with T3 possessed the highest gain and consumption. Diet did not affect feed conversion ratio (Table 5).

\section{DISCUSSION}

In the current study, we documented that dietary supplementation of either formic acid, $S$. cerevisiae or combination of both did not affect the $\mathrm{pH}$ values of gut segments of IICC. Previously, Hernández et al. (2006) noted that formic acid supplementation had no impact on the $\mathrm{pH}$ values of intestine particularly jejunum of broiler chickens. Yet, other studies showed that

Table 3. Intestinal Morphology of IICC Fed Experimental Diets

\begin{tabular}{|c|c|c|c|c|c|}
\hline \multirow{2}{*}{ Items } & \multicolumn{4}{|c|}{ Treatments } & \multirow{2}{*}{$\mathrm{P}$ value } \\
\hline & T0 & $\mathrm{T} 1$ & $\mathrm{~T} 2$ & $\mathrm{~T} 3$ & \\
\hline \multicolumn{6}{|c|}{ Duodenum $(\mu \mathrm{m})$} \\
\hline Villi height & $952 \pm 104^{b}$ & $999 \pm 191^{b}$ & $1027 \pm 67.9^{\mathrm{b}}$ & $1566 \pm 314^{\mathrm{a}}$ & $<0.01$ \\
\hline Villi width & $237 \pm 36.6^{\mathrm{ab}}$ & $208 \pm 34.7^{\mathrm{b}}$ & $201 \pm 70.8^{b}$ & $301 \pm 74.9^{\mathrm{a}}$ & 0.04 \\
\hline Crypt depth & $264 \pm 42.8^{\mathrm{c}}$ & $330 \pm 58.5^{b c}$ & $411 \pm 71.9^{b}$ & $560 \pm 98.7^{\mathrm{a}}$ & $<0.01$ \\
\hline \multicolumn{6}{|l|}{ Jejunum $(\mu \mathrm{m})$} \\
\hline Villi height & $749 \pm 415^{\mathrm{b}}$ & $883 \pm 257^{\mathrm{ab}}$ & $938 \pm 139^{\mathrm{ab}}$ & $1223 \pm 242^{\mathrm{a}}$ & 0.04 \\
\hline Villi width & $149 \pm 26.3$ & $205 \pm 65.7$ & $207 \pm 46.5$ & $201 \pm 57.1$ & 0.25 \\
\hline Crypt depth & $209 \pm 50.2^{\mathrm{b}}$ & $219 \pm 29.7^{b}$ & $296 \pm 62.1^{b}$ & $428 \pm 95.9^{\mathrm{a}}$ & $<0.01$ \\
\hline \multicolumn{6}{|l|}{ Ileum $(\mu \mathrm{m})$} \\
\hline Villi height & $476 \pm 82.2^{\mathrm{c}}$ & $672 \pm 117^{b}$ & $764 \pm 98.0^{b}$ & $967 \pm 123^{\mathrm{a}}$ & $<0.01$ \\
\hline Villi width & $234 \pm 79.8$ & $267 \pm 86.1$ & $210 \pm 55.4$ & $252 \pm 82.3$ & 0.68 \\
\hline Crypt depth & $203 \pm 54.1^{b}$ & $225 \pm 49.9^{b}$ & $265 \pm 60.1^{\mathrm{b}}$ & $412 \pm 137^{\mathrm{a}}$ & $<0.01$ \\
\hline
\end{tabular}

a,b,c Values in the same row with various letters indicate substantial differences at $\mathrm{P}<0.05$

T0: unsuplemented feed (control), T1: T0 $+0.2 \%$ formic acid, T2: T0 $+0.3 \%$ S. cerevisiae, T3: T0 $+0.2 \%$ formic acid $+0.3 \%$ S. cerevisiae 
Table 4. Protein Digestibility and Nitrogen Retention of IICC Fed Experimental Diets

\begin{tabular}{lccccc}
\hline \multirow{2}{*}{ Items } & \multicolumn{5}{c}{ Treatments } \\
\cline { 2 - 6 } & T0 & T1 & T2 & T3 & \\
\hline Crude protein intake $(\mathrm{g})$ & $13.6 \pm 1.42$ & $13.7 \pm 1.31$ & $15.7 \pm 1.21$ & $15.1 \pm 1.43$ & 0.06 \\
Fecal crude protein $(\mathrm{g})$ & $4.86 \pm 1.04^{\mathrm{a}}$ & $2.79 \pm 0.61^{\mathrm{b}}$ & $5.02 \pm 0.98^{\mathrm{a}}$ & $4.41 \pm 0.79^{\mathrm{a}}$ & $<0.01$ \\
Digestible crude protein (g) & $8.78 \pm 0.73$ & $10.9 \pm 1.70$ & $10.7 \pm 1.60$ & $10.7 \pm 1.95$ & 0.15 \\
Crude protein digestibility & $64.6 \pm 4.77^{\mathrm{b}}$ & $79.3 \pm 6.15^{\mathrm{a}}$ & $67.9 \pm 6.85^{\mathrm{b}}$ & $70.4 \pm 7.04^{\mathrm{b}}$ & 0.01 \\
coefficient (\%) & & & & & \\
Nitrogen retention (g) & $1.41 \pm 0.12$ & $1.74 \pm 0.27$ & $1.71 \pm 0.26$ & $1.71 \pm 0.31$ & 0.14 \\
\hline
\end{tabular}

a,b,c Values in the same row with various letters indicate substantial differences at $\mathrm{P}<0.05$

T0: unsuplemented feed (control), T1: T0 + 0.2\% formic acid, T2: T0 + 0.3\% S. cerevisiae, T3: T0 + 0.2\% formic acid $+0.3 \%$ S. cerevisiae

Table 5. Performance of IICC Fed Experimental Diets

\begin{tabular}{lcccccccccc}
\hline \multirow{2}{*}{ Items } & \multicolumn{1}{c}{ Treatments } & \multicolumn{1}{c}{ T3 } & \\
\cline { 2 - 10 } & \multicolumn{1}{c}{ T0 } & \multicolumn{1}{c}{ T1 } & \multicolumn{1}{c}{ T2 } & \multicolumn{2}{c}{ T3 ue } \\
\hline Weight gain (g/bird) & $784 \pm 20^{\mathrm{d}}$ & 900 & \pm & $15^{\mathrm{c}}$ & 1057 & $\pm 18^{\mathrm{b}}$ & 1122 & $\pm 19^{\mathrm{a}}$ & $<0.01$ \\
Feed intake (g/bird) & $2334 \pm 292^{\mathrm{c}}$ & 2887 & $\pm 224^{\mathrm{b}}$ & 3068 & $\pm 211^{\mathrm{ab}}$ & 3194 & $\pm 46^{\mathrm{a}}$ & $<0.01$ \\
FCR $(\mathrm{g} / \mathrm{g})$ & $2.84 \pm$ & 0.35 & $3.08 \pm$ & 0.30 & $2.80 \pm$ & 0.23 & $2.75 \pm 0.06$ & 0.23 \\
\hline
\end{tabular}

a,b,c,d Values in the same row with various letters indicate substantial differences $(\mathrm{P}<0.05)$

T0: unsuplemented feed (control), T1: T0 + 0.2\% formic acid, T2: T0 $+0.3 \%$ S. cerevisiae, T3: T0 $+0.2 \%$ formic acid $+0.3 \%$ S cerevisiae; FCR: feed conversion ratio

formic acid supplementation reduced $\mathrm{pH}$ values of the entire segments of gastrointestinal tract of broilers (Ragaa and Korany, 2016). With regard to $S$. cerevisiae, such probiotic treatment had no substantial impact on the $\mathrm{pH}$ values of gut of IICC in the present study. This result is similar to what reported by Sacakli et al. (2011) who did not see any impact of $S$. cerevisiae on the $\mathrm{pH}$ values of intestine. This was, however, in contrast to Elghandour et al. (2019) confirming that $S$. cerevisiae could reduce $\mathrm{pH}$ values of broiler gut. There is no definite explanation for these divergent data above, but the different strains of chickens, doses of formic acid and S. cerevisiae and rearing conditions may exert different responses of chicks in terms of gut $\mathrm{pH}$. The supplementations using formic acid, S. cerevisiae or their blends resulted in no effect on the bacterial populations in the gut of IICC. It has widely been known that low $\mathrm{pH}$ or acidic condition may implicate in the reduced pathogenic bacteria while increase the populations of lactic acid bacteria in the gut of chickens (Ndelekwute et al., 2018). For this reason, the absent difference in $\mathrm{pH}$ values seemed to be associated wih the lack difference in the populations of coliform, lactose-negative enterobacteria and lactic acid bacteria in the intestinal segments of IICC.

In the former study, Ragaa and Korany (2016) showed the efficacy of formic acid in increasing the villi height of broiler chickens. In this study, formic acid increased villi height of ileum of IICC, while the effect of such organic acid was moderate in villi height of duodenum and jejunum. It was very likely that the antibacterial activity of formic acid may reduce the colonization of pathogenic bacteria and thus 
diminish the inflammatory process at the mucosa of intestine. The latter condition may consequently increase villus hight (Ragaa and Korany, 2016). With regard to S. cerevisiae, the probiotic activity of the yeast seemed to increase the villus height of ileum of IICC. In agreement with our data, Padihari et al. (2014) reported that $S$. cerevisiae increased villi height of the intestine in broiler chickens. They further confirmed that in addition to the probiotic activity of $S$. cerevisiae in inhibiting the proliferation of pathogenic bacteria, S. cerevisiae may also stimulate the development of intestinal villi through improving the mucosal cell proliferation. It is also shown in this study that $S$. cerevisiae increased the duodenal crypt depth of IICC. In agreement with this result, Peralta et al. (2018) also showed that feeding $S$. cerevisiae moderately increased the crypt depth of intestine of broilers. According to the latter authors, the deeper crypt depth may be attributed to the increased intestinal tissue turnover due to rapid immune response of chicks against pathogens. Different from our results, other study by Sacakli et al. (2011) did not find any influence of $S$. cerevisiae on the crypt depth of intestine of broilers. The combination of formic acid and $S$. cerevisiae resulted in higher villi hight, wider villi width and deeper crypt depth. In this study, the synergistic effect of formic acid and $S$. cerevisiae seemed to occur.

Data in the current work showed that crude protein digestibility coefficient was substantially higher in the IICC supplemented with formic acid. Similar to our finding, Ragaa and Korany (2016) documented that treatment with formic acid improved the digestibility coefficient of crude protein in broilers. They also suggested that formic acid could increase the activity of pepsin and thus enhance gastric proteolysis and raise the digestibility of protein and amino acids. Our data also revealed that formic acid reduced fecal crude protein in IICC. It was very likely that the increased gastric proteolysis may contribute to the increased protein digestibility and utilization, resulting in less content of crude protein in excreta of IICC. In this experiment, dietary supplementation of $S$. cerevisiae possessed no effect on the protein digestibility and nitrogen retention of IICC. This was in contrast to Elghandour et al. (2019) who documented that $S$. cerevisiae improved crude protein digestibility in broiler chickens. It seemed that the differences in chicken strains as well as experimetal protocols may be associated with the conflicting data above.

It was apparent in this study that treatments using either formic acid, probiotic S. cerevisiae or the blends of both was associated with the improved weight gain of IICC. The higher weight gain was associated with the increased feed intake in the treated IICC. Also, the improved intestinal morphology and thus digestive and absorptive capacity may be attributed to the increased weight gain of the treated chicks.

\section{CONCLUSION}

The inclusion of formic acid and $S$. cerevisiae in diets improved intestinal ecology and morphology. The IICC chickens fed with formic acid and S. cerevisiae exhibited improved growth performance and nutrient digestibility.

\section{REFERENCES}

Ahmad, R.Z. 2005. The advantage of yeast Saccharomyces cerevisiae for livestock. Wartazoa. 15(1):49-55.

Awad, W.A., K. Ghareeb, S. Abdel-Raheem and J. Böhm. 2009. Effects of dietary inclusion of probiotic and synbiotic on growth performance, organ weights, and intestinal histomorphology of broiler chicken. Poult. Sci. 88(1):49-55.

Darmawan, I., E. Suprijatna and U. Atmomarsono. 2017. Effect of Frequency and feeding period on carcass production in crossbred native chicken. Indonesian $\mathrm{J}$. Anim. Sci. 19(1): 10-15.

Elghandour, M.M.Y., Z.L. Tan, S.H.A. Hafsa, M.J. Adegbeye, R. Greiner, E.A. Ugbogu, J.C. Monroy and A.Z.M. Salem. 2019. Saccharomyces cerevisiae as a probiotic feed additive to non and pseudo-ruminant feeding: a review. J. Appl. Microbiol. 128(3):658-674.

Garcia, V., P.C. Gregori, F. Hernandez, M.D. Megias and J. Madrid. 2007. Effect of formic acid and plant extracts on growth, nutrient digestibility, intestine mucosa morphology, and meat yield of broilers. J. Appl. Poult. Res. 16(4):555-562.

Harimurti, S. and E. S. Rahayu. 2009. Morphology of small intestinal broiler chickens supplemented with single and mixed probiotic strains. Agritech. 29(3):179183.

Herlina, B. and W. Ibrahim. 2019. Penambahan tepung daun salam dalam ransum terhadap 
konsumsi ransum, bobot potong, bobot karkas dan organ dalam ayam kampung super. Jurnal Sain Peternakan Indonesia. 14(3):259-264 (full article in Bahasa).

Hernández, F., V. García, J. Madrid, J. Orengo, P. Catalá and M.D. Megías. 2006. Effect of formic acid on performance, digestibility, intestinal histomorphology and plasma metabolite levels of broiler chickens. Br. Poult. Sci. 47(1):50-56.

Kompiang, I.P. 2002. Effect of yeast: Saccharomyces cerevisiae and marine yeast as probiotic supplement on performance of poultry. J. Vet. Anim. Sci. 7(1):18-21.

Koyuncu, S., M.G. Andersson, C. Löfström, P.N. Skandamis, A. Gounadaki, J. Zentek and P. Häggblom. 2013. Organic acids for control of Salmonella in different feed materials. BMC. Vet. Res. 9(81):1-9.

Li, P., A.L. Lawrence, F.L Castille and D.M. Gatlin. 2007. Preliminary evaluation of a purified nucleotide mixture as dietary supplement for Pacific white shrimp (Litopenaeus vannamei). Aquacult. Res. 38(8):887-90.

Padihari, V.P., S.P. Tiwari, T. Sahu, M.K. Gendley and S.K. Naik. 2014. Effects of mannan oligosaccharide and Saccharomyces cerevisiae on gut morphology of broiler chickens. J. World's Poult. Res. 4(3):56-59.

Pathak, M., G.P. Mandal, A.K. Patra, I. Sumanta, S. Pradhan and S. Haidar. 2017. Effect of dietary supplementation of cinnamaldehyde and formic acid on growth performance, intestinal microbiota and immune response in broiler chickens. Anim. Prod. Sci. 57(5):821-827.

Peralta, M.F., A.J. Nilson and R.D. Miazzo. 2018. Effect of Saccharomyces cerevisiae association with threonine on productive performance in broilers. Iranian. J. Applied. Anim. Sci. 8(4):677-684.

Ragaa, N.M. and R.M.S. Korany. 2016. Studying the effect of formic acid and potassium diformate on performance, immunity and gut health of broiler chickens. Anim. Nutr. 2(4):296-302.

Ramli, N., D.M. Suci, S. Sunanto, C. Nugraheni, A. Yulifah and A. Sofyan. 2008. Performan ayam broiler yang diberi ransum mengandung potassium diformate sebagai pengganti flavomycin. Agripet. 8(1):1-8 (full article in Bahasa).

Sacakli, P., A. Ergun, B.H. Koksal, A.G. Bayraktaroglu and O. Sizmaz. 2011. Effects of diets supplemented with yeast (Saccharomyces cerevisiae) products or/andhops (Humulus iupulus) on growth performance and intestinal morphology in broilers. Revue Méd. Vét. 162(11):531-537.

Steel, R.G.D. and J.H. Torrie. 1997. Principles and Procedures of Statistics. McGraw-Hill Book Co. Inc. New York.

Sugiharto, T. Yudiarti and I. Isroli. 2019. Growth performance, haematological parameters, intestinal microbiology, and carcass characteristics of broiler chickens fed twostage fermented cassava pulp during finishing phase. Trop. Anim. Sci. J. 42(2):113-120.

Sugiharto, T. Yudiarti, I. Isroli and E. Widiastuti. 2018. The physiological responses to dietary administration of zinc bacitracin and Bacillus mixture on low-weight day-old chicks. Poult. Sci. J. 6(1):51-62.

Sugiharto. 2016. Role of nutraceuticals in gut health and growth performance of poultry. J. Saudi. Soc. Agric. Sci. 15(2):99-111.

Tillman, A.D. 1998. Basic animal feed sciences. (H. Hartadi, S. Reksohadiprodjo, S. Prawirokusumo, and S.L Soekotjo). Gadjah Mada University Press. Yogyakarta. 442.

Widodo, T.S., B. Sulistiyanto and C.S. Utama. 2015. Jumlah bakteri asam laktat (BAL) dalam digesta usus halus dan sekum ayam broiler yang diberi pakan ceceran pabrik pakan yang difermentasi. Agripet. 15(2):98103 (in Indonesian). 